\title{
Tomato genotypes grown under phosphorus deficiency
}

\section{stress}

\author{
Marques DJ*, Pereira MMA, Bianchini HC and Batista DE \\ 1Universidade José do Rosário Vellano (UNIFENAS), Campus Universitário, Minas \\ Gerais, Brasil
}

*Corresponding author: Douglas José Marques, Setor de Olericultura e

\section{Research Article \\ Volume 3 Issue 2}

Received Date: February 10, 2018

Published Date: March 02, 2018 Experimentação em Agricultura Orgânica, Universidade José do Rosário Vellano, Faculdade de Agronomia, Brasil, E-mail: douglasjmarques81@yahoo.com.br

\section{Abstract}

The increase in phosphorus absorption efficiency by tomato plants can lead to a reduction in the phosphorus fertilizer rates used, as well as, possibly, the immediate use of $\mathrm{P}$ fixed in the soil. Thus enabling consequences favorable to agricultural sustainability, net revenue of farmers and taking advantage of marginal areas. In this way, this study aimed to evaluate the efficiency of absorption and utilization of phosphorus in three genotypes of tomato plants grown on different levels of P205. It was used the randomized block design, in a factorial 3 x 5 (three tomato genotypes: Globonnie, Tom-598 and F1 [Tom-598 x Globonnie]) and five P rates: (0, 150, 300, 450 and $600 \mathrm{mg} \mathrm{kg}-1$ soil), with four replications. They were evaluated in the study dry matter of root, stem, leaf, photosynthetic rate, content of green color using the portable chlorophyll meter SPAD, phosphorus content, absorption efficiency and phosphorus use efficiency. It is concluded with the research on tomato crops that increasing P205 doses provided: 1) lower dry matter of stem, root and leaf in F1; 2) higher intensity of the green color, measured by SPAD (portable chlorophyll meter) in Tom-598 and Globonnie; 3) higher photosynthetic rate in Globonnie; 4) higher phosphorus accumulation in Tom-598; 5) greater efficiency of phosphorus absorption and utilization, applied at lower doses in Globonnie and 6) higher efficiency of P utilization by Globonnie, independent of the dose used, demonstrating expression of the crt gene (Cotton root).

Keywords: Solanum lycopersicon; Efficiency; Phosphorus; Resistance; Tom-598

\section{Introduction}

The tomatoes for fresh consumption are produced in practically all geographic regions of Brazil, at different seasons, under different cropping systems and different levels of crop management. It stands out as the second most cultivated vegetable in the world, second only to potatoes. The segment of tomato for consumption accounts for $63.4 \%$ of production (2.34 million tonnes) and the remaining $36.6 \%$ are intended for industrial processing (1.35 million t) [1]. Assessing the national scene, it is observed that maximum yield in tomato crop have been associated with fertilizer doses exceeding 300 


\section{Open Access Journal of Agricultural Research}

$\mathrm{kg}$ P205 per hectare and is often applied doses that reach $1200 \mathrm{~kg}$ of P2 per hectare [2].

Although the productive efficiency of tomato plants is associated with the use of large doses of mineral fertilizers, the increase of efficiency in phosphorus absorption (P) from tomato plant is of utmost importance to reduce the phosphate fertilizers utilization, as well as providing immediate absorption of $\mathrm{P}$ fixed in the soil by dissolving the labile $\mathrm{P}$, maintaining the $\mathrm{P}$ balance in the solution [3]. The primary source of phosphate fertilizers are natural phosphates originated from igneous or metamorphic, and, many surveys estimate that global reserves of these rocks will beextinct in 50 to 100 years [4]. This high exploitation of raw materials reinforces the importance of researches that aimed at studying efficient genotypes in the phosphorus utilization, which will promote the agricultural sustainability, increase in net income of farmers, greater use of marginal areas in terms of soil fertility, factors these that will favor the savings of fertilizers at the national level. According to Silva \& Maluf [2], a reduction of $100 \mathrm{~kg}$ of P205 ha-1 may represent an average reduction of production cost of $£ 200.00$ ha-1, presenting annual savings of more than $£ 11$ million for the national tomato production.

Phosphorus is a nutrient required in large amounts by plants and its wide spread deficiency in most Brazilian soils, as in weathered tropical soils, especially clay soils, much of the $\mathrm{P}$ added is retained by high energy bonds ( $\mathrm{P}$ not labile). The plants show significant differences in the use of phosphorus efficiency. The ability to tolerate stress deficiency of this nutrient, is due to inter and intraspecific genetic variation for translocation, distribution and phosphorus utilization [5]. The efficiency for the absorption of $\mathrm{P}$ by genotypes can be achieved through alterations in root architecture or morphology and their capacity of association with microorganisms [6]. In roots, exudation of mobilizing components of $\mathrm{P}$ may vary in relation to metabolism, age and genetic material of each plant as well as changes in Pi transporters of plasma membrane [7]. Additionally, changes aimed at the application of smaller amounts of $\mathrm{P}$ at the cellular level or a more efficient remobilization of $\mathrm{P}$ within the plant will favour its absorption efficiency.

The availability of tomato germplasm, effective in extraction at lower phosphorus levels, associated with a morphological characteristic of this plant (the presence of large numbers of root hairs) that is controlled by a recessive gene [8], makes species Solanum lycopersicon appropriate for genetic improvement objectifying an increase in the phosphorus absorption efficiency. The objective was to evaluate the efficiency of absorption and utilization of $\mathrm{P}$ in three genotypes of tomato plants grown on different levels of P2O5.

\section{Materials and Methods}

The experiment was conducted in Horticulture and Experimentation sector at the University José do Rosário Vellano-UNIFENAS, Alfenas MG in 2013, Brazil. It was used the randomized block design, in factorial 3 (three tomato genotypes belonging to the germplasm bank of the University José Rosário Vellano - UNIFENAS and professor Wilson Roberto Maluf of the Department of Agriculture of the Universidade Federal deLavras. Brazil The genotypes globonnie belongs to the cherry group (wild material), already the Tom 598 belongs Santa Cruz.: Globonnie, Tom-598 and F1 [Tom-598 x Globonnie]) versus5 phosphorus concentrations: $(0,150,300,450$ and $600 \mathrm{mg}$ P205 kg-1 soil), with four replications. The fertilization and the determination of phosphorus dose for each treatment were made as proposed by Novais, et al. [9]. The soil was collected in the UNIFENAS and it is classified as Oxisol of clayey textural class [10]. Was made sieving using sieve with a5 $\mathrm{mm}$ mesh and then submitted to chemical characterization analyzes in the Natural Resources laboratory of UNIFENAS. Initially the soil had the following chemical characteristics: $\mathrm{pH}(\mathrm{H} 2 \mathrm{O})=5.6$; PMehlich(mg dm-3) = 7; K (mmolc dm-3)= 1.1; Ca (mmolc $\mathrm{dm}-3)=6 ; \mathrm{Mg}($ mmolc $\mathrm{dm}-3)=4 ; \mathrm{SB}($ mmolcdm 3$)=11$; $\mathrm{H}+\mathrm{Al}(\mathrm{mmolcdm} 3)=21 ; \mathrm{V} \%=35 ; \mathrm{t}=11 \mathrm{~T}=32$ and organic matter $(\mathrm{mgdm} 3)=14$.

The calculations for soil acidity correction followed the recommendations of Novais, et al. [9], aimed at raising the base saturation to $80 \%$, being necessary to apply the equivalent of $4.5 \mathrm{~g}$ of dolomitic limestone (PRNT $=100 \%$ ) per pot.

After liming, the soil was incubated for 30 day so that occurred the reaction between the lime with the soil and subsequently was sowed the seeds in plastic trays with 128 cells, using the substrate expanded vermiculite. The seedlings remain in the nursery until they reach four pairs of true leaves, which occurred 30 days after sowing. Then was transplanted a seedling in pot with $6 \mathrm{dm}-3$ of soil capacity each. The fertilization at sowing was made in accordance to the treatments and recommendations for the crop, and the coverage fertilizations of $\mathrm{N}$ (urea) and K2O (potassium chloride) were divided in 3 applications with an interval of 15 days. After the end of the experiment was made a new chemical analysis of soil (Table 1). 


\section{Open Access Journal of Agricultural Research}

\begin{tabular}{|c|c|c|c|c|c|c|c|c|c|c|c|c|}
\hline \multirow{2}{*}{ Genótipos } & \multirow{2}{*}{$\begin{array}{c}\text { Doses } P \\
\text { (mg kg solo) }\end{array}$} & \multirow{2}{*}{$\begin{array}{r}\mathrm{pH} \\
\mathrm{H}_{2} \mathrm{O} \\
\end{array}$} & \multirow{2}{*}{$\begin{array}{c}\text { P }_{\text {Mehlich }} \\
\text { mg dm }^{3} \\
\end{array}$} & $\mathbf{S b}$ & $\mathbf{t}$ & $\mathbf{T}$ & $\mathrm{H}+\mathrm{Al}$ & $\mathbf{K}$ & Ca & Mg & Al & \multirow{2}{*}{$\begin{array}{l}\mathrm{V} \\
\% \\
\end{array}$} \\
\hline & & & & \multicolumn{8}{|c|}{ 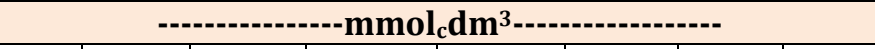 } & \\
\hline Tom-598 & 0 & 5,6 & 0,5 & 18 & 18 & 47 & 29 & 2,1 & 11 & 6 & 0 & 39 \\
\hline Tom-598 & 150 & 5,8 & 36 & 31 & 31 & 64 & 33 & 1,5 & 22 & 7 & 0 & 48 \\
\hline Tom-598 & 300 & 5,6 & 102 & 41 & 41 & 77 & 36 & 1,4 & 32 & 7 & 0 & 53 \\
\hline Tom-598 & 450 & 5,7 & 162 & 44 & 44 & 70 & 26 & 3,5 & 32 & 8 & 0 & 63 \\
\hline Tom-598 & 600 & 5,5 & 241 & 53 & 53 & 84 & 31 & 2,3 & 42 & 9 & 0 & 63 \\
\hline Globonnie & 0 & 5,5 & 1 & 20 & 20 & 39 & 19 & 3,0 & 12 & 5 & 0 & 52 \\
\hline Globonnie & 150 & 5,4 & 29 & 28 & 28 & 50 & 22 & 1,4 & 21 & 6 & 0 & 56 \\
\hline Globonnie & 300 & 5,3 & 117 & 38 & 38 & 69 & 31 & 1,4 & 29 & 7 & 0 & 55 \\
\hline Globonnie & 450 & 5,4 & 166 & 50 & 50 & 83 & 33 & 2,6 & 39 & 8 & 0 & 60 \\
\hline Globonnie & 600 & 5,5 & 239 & 61 & 64 & 95 & 34 & 2,0 & 49 & 9 & 0,3 & 64 \\
\hline$F 1$ & 0 & 5,7 & 14 & 19 & 19 & 40 & 21 & 1,9 & 11 & 6 & 0 & 47 \\
\hline$F 1$ & 150 & 5,6 & 37 & 28 & 28 & 56 & 28 & 1,5 & 19 & 7 & 0 & 50 \\
\hline$F 1$ & 300 & 5,4 & 93 & 41 & 41 & 70 & 29 & 1,3 & 33 & 7 & 0 & 59 \\
\hline$F 1$ & 450 & 5,6 & 156 & 46 & 46 & 72 & 26 & 2,8 & 36 & 7 & 0 & 64 \\
\hline$F 1$ & 600 & 5,7 & 232 & 73 & 73 & 98 & 25 & 2,1 & 58 & 12 & 0 & 74 \\
\hline
\end{tabular}

Table 1: Chemical analysis of the soil after the end of the experiment.

The following evaluations were made: root dry matter $(\mathrm{g})$, stem $(\mathrm{g})$ and leaf $(\mathrm{g})$; photosynthetic rate $(\mu \mathrm{mmol} \mathrm{m}-2$ $\mathrm{s}-2$ ); content of green color using the portable chlorophyll meter SPAD, phosphorus content (g kg-1), absorption efficiency (EA) of $\mathrm{P}$ (g mg-1) and phosphorus utilization efficiency (EU) of $\mathrm{P}$ (g mg-1).

The dry matter of the root, stem and leaf were quantified at the end of the experiment. Samples were separated and packed in paper bags and placed in forced air chamber at $65^{\circ} \mathrm{C}$, then was realized the weighing of these materials in electronic precision scale (Mars, AD500 $S$ model). The chlorophyll rate was quantified using portable chlorophyll meter (SPAD-502 - Minolta Camera Co., Ltd.), which provides instantaneous reading in a nondestructive manner in the evaluation of the nitrogen content of the leaf in real time due to significant correlation between the intensity of the green color and chlorophyll content. It was standardized using two lateral leaves and terminal leaf of each plant.

For the determination of photosynthesis was carried out a specific measurement at 50 days after transplanting, standardizing two lateral and the terminal leaf, in the middle third of the plants. For photosynthesis response curves to photosynthetically active radiation and $\mathrm{CO} 2$ concentration were conducted measurements at 6 o'clock in the morning. For these punctual measurements, the irradiance was maintained at $500 \mathrm{mmol} \mathrm{m}-2 \mathrm{~s}-1$, value above the irradiance of light saturation of the control plants. The liquid photosynthetic rates per unit leaf area, stomatal conductance to water vapor, stomatal resistance to water vapor, leaf transpiration rate, conductance sub stomatal, leaf temperature and photosynthetic active radiation were estimated from the values of $\mathrm{CO} 2$ variation and air humidity inside the chamber, using the portable meter IRGA, LI-6400 model.

The quantification of phosphorus concentration in leaf tissue was made to DAT 100, in the leaf analysis laboratory of the Science Soil Department in the Universidade Federal de Lavras, Minas Gerais, according to the methodology described by Malavolta, et al. [11]. The efficiency of acquisition and use of P2O5 (EAQ and EUTIL) and its components were described by the expressions: Acquisition Efficiency of P2O5 (EAQ = total P content in the leaf/ Quantity of $\mathrm{P}$ in soluble solution) and Utilization Efficiency (EUTIL = tomato Production/total P in the leaf) in (mg kg-1).For the evaluation of average in the analysis of variance were applied Scott-Knott test or ttest, according to the theory suggested by Steel; Torrie Dickey (2006). The standard deviations were applied estimators of regression and correlation (Pearson or Spearman), using the SISVAR software [12]. 


\section{Open Access Journal of Agricultural Research}

\section{Results and Discussion}

For the production of dry matter of root, stem and leaf were no significant differences for the interaction (P205 doses) $\mathrm{x}$ (Globonnie, Tom-598 and F1 [Tom-598 x Globonnie]), the results of this interaction are presented in Table 2.For the F1 genotype there was a higher production of dry root in doses of 150 and $300 \mathrm{mg} \mathrm{kg}-1$ P205 for the Tom-598 at a dose of $300 \mathrm{mg} \mathrm{kg}-1$ of P2O5 and the Globonnie at doses 150 and $300 \mathrm{mg}$ kg-1 P205. In the interaction (P205 doses) $x$ (Globonnie, Tom-598 and F1 [Tom-598 x Globonnie]), the dry matter production of roots was higher in Globonnie, in the smaller doses ( 0 and 150 doses of $150 \mathrm{mg}$ P205). For Tom-598, considered controlling cultivar, from $300 \mathrm{mg}$ kg-1 of P2O5 there was an increased of dry matter production of roots. The highest yield observed in Globonnie demonstrates the expression of the CRT gene (Cotton root) in the tomato plants. For the dry matter production of stems the higher values for F1were observed at doses of 300 and 450, for Tom-598 in a dose of 150 and for the Globonnie at a dose of $300 \mathrm{mg} \mathrm{kg}-1$ of P205. There was interaction between Tom-598 and F1 for P205 doses xcontrol genotypes of P205. The production of dry matter in the leaf was higher at doses of 150 and $300 \mathrm{~kg}-1$ of P205 for Globonnie, Tom598 and F1. Studies suggest that in tomato plants leaf is the primary photoassimilates drain, followed by stems and fruits [13]. On the conduct of the genotypes, depending on P205 doses, lower production of dry matter of leaves were obtained for genotypes that produced fewer leaves. Silva \& Maluf [2] evaluating the phosphorus absorption efficiency in two tomato genotypes, observed that the dry aerial part mass of the TOM-598 reduced with decreasing concentration of P, whereas PI 121665 showed an increase.

The increase in dry matter concentration of the root, for Globonnie genotype is indicative of probable strategy of plants for phosphorus acquisition in deficient conditions. Marques, et al. (2007) [14], working with low doses of phosphorus, concluded that Globonnie genotype produced a larger amount of thin roots. In larger doses of P205 Tom-598 produced the largest volume of roots. These results are consistent with findings in the literature, where it is found that commercial genotypes respond efficiently to higher phosphorus levels. Dovale \& Fritsche-Neto (2013) [15], observed that the selection of tomato genotypes based on the performance of hybrids in relation to dry aerial part mass, makes it possible to obtain access to high efficiency of phosphorus use. According to Svistoonoff, et al. (2007) [16], the root elongation induced by $\mathrm{P}$ deficiency is a visible marker to study the response of plants to nutritional stress.

\begin{tabular}{|c|c|c|c|}
\hline \multirow{2}{*}{$\begin{array}{c}\mathrm{P}_{2} \mathrm{O}_{5} \text { rates } \\
\text { (mg kg-1 } \\
\text { soil) }\end{array}$} & \multicolumn{3}{|c|}{ Genotypes } \\
\hline & F1 & Tom-598 & Globonnie \\
\hline & \multicolumn{3}{|c|}{ Dry matter of leaves (g plant ${ }^{-1}$ ) } \\
\hline 0 & $1,27 \mathrm{Bb}$ & $1,53 \mathrm{Ba}$ & $1,15 \mathrm{Ab}$ \\
\hline 150 & $1,67 \mathrm{Ab}$ & $2,29 \mathrm{Ba}$ & $2,31 \mathrm{Aa}$ \\
\hline 300 & $1,81 \mathrm{Ab}$ & $3,28 \mathrm{Aa}$ & $2,32 \mathrm{Aa}$ \\
\hline 450 & $1,56 \mathrm{Ab}$ & $2,38 \mathrm{Ba}$ & $1,33 \mathrm{Bb}$ \\
\hline 600 & $1,45 \mathrm{Aa}$ & $1,73 \mathrm{Ba}$ & $1,70 \mathrm{Ba}$ \\
\hline \multirow[t]{2}{*}{$\mathbf{R}^{2}$} & $85,04 \%$ & $59,94 \%$ & $\mathbf{7 8 , 8 0 \%}$ \\
\hline & \multicolumn{3}{|c|}{ Dry matter of stem ( g plant $^{-1}$ ) } \\
\hline 0 & $3,99 \mathrm{Ca}$ & $3,51 \mathrm{Ba}$ & $2,96 \mathrm{Cb}$ \\
\hline 150 & $5,92 \mathrm{Ba}$ & 8,73 Аа & $6,93 \mathrm{Ba}$ \\
\hline 300 & 7,69 Aa & $9,24 \mathrm{Aa}$ & $8,22 \mathrm{Aa}$ \\
\hline 450 & $6,54 \mathrm{Aa}$ & $9,44 \mathrm{Aa}$ & $8,64 \mathrm{Aa}$ \\
\hline 600 & $6,48 \mathrm{Ac}$ & 7,64 Аa & $8,28 \mathrm{Aa}$ \\
\hline \multirow[t]{2}{*}{$\mathbf{R}^{2}$} & $\mathbf{7 7 , 5 3 \%}$ & $98,05 \%$ & $\mathbf{7 5 , 4 6 \%}$ \\
\hline & \multicolumn{3}{|c|}{ Dry matter of roots (g plant $\left.{ }^{-1}\right)$} \\
\hline 0 & $1,03 \mathrm{Bb}$ & $0,99 \mathrm{Cb}$ & $1,75 \mathrm{Ba}$ \\
\hline 150 & $1,66 \mathrm{Ab}$ & $1,55 \mathrm{Bb}$ & $2,56 \mathrm{Aa}$ \\
\hline 300 & $2,06 \mathrm{Ab}$ & $3,22 \mathrm{Aa}$ & $2,27 \mathrm{Ab}$ \\
\hline 450 & $1,40 \mathrm{Bb}$ & $2,71 \mathrm{Ba}$ & $1,17 \mathrm{Bb}$ \\
\hline 600 & $1,29 \mathrm{Bb}$ & $2,13 \mathrm{Ba}$ & $1,83 \mathrm{Bb}$ \\
\hline $\mathbf{R}^{2}$ & $88.51 \%$ & $55.24 \%$ & $98.58 \%$ \\
\hline
\end{tabular}

Table 2: Dry matter mass average of stem, root and leaves of tomato genotypes grown in different phosphorus concentrations.

Averages followed by the same capital letter in the column do not differ with each other by the Scott-Knott test, at $5 \%$ significance level. Averages followed by the same lowercase letter on the line, do not differ with each other by the Scott-Knott test, at 5\% significance level. He increase of the intensity of green color, measured by portable chlorophyll meter (SPAD), in the Tom-598 and Globonnie genotypes, due to the high doses of P205 (Figure 1), can be explained by the action of phosphorus in the essential compounds to plant metabolism, as adenosines, phospholipids, nucleic acids, which participate in the respiration and photosynthesis. The phosphorus deficiency in plants reduces the ATP and $\mathrm{NADPH}$ which contributes to lower carboxylation/regeneration of implying decrease in $\mathrm{P}$ between the cytoplasm and the stroma [17]. Also occurs assimilated accumulation (sucrose and starch) in the chloroplast, affecting the photosynthesis through the stomatal closure and lower conductance of mesophyll.

For the F1 genotype was found a decrease in the intensity of green color with the increase of P205, this can 


\section{Open Access Journal of Agricultural Research}

be attributed to the high $\mathrm{P}$ concentration in plant tissues, which possibly reduced photosynthesis rate, impairing the formation of photosynthetic pigments responsible for the solar energy catchment and photoassimilates formation [18]. For the F1 genotype (Figure 1A) and Tom598 (Figure 1B) downward trend was observed in the intensity of green color from $300 \mathrm{mg} \mathrm{kg}-1 \mathrm{P} 205$. In Globonnie (Figure 1C), the green color intensity increased with the growth of the P205 levels. In F1 there was less intensity of the green color when compared to other genotypes studied.

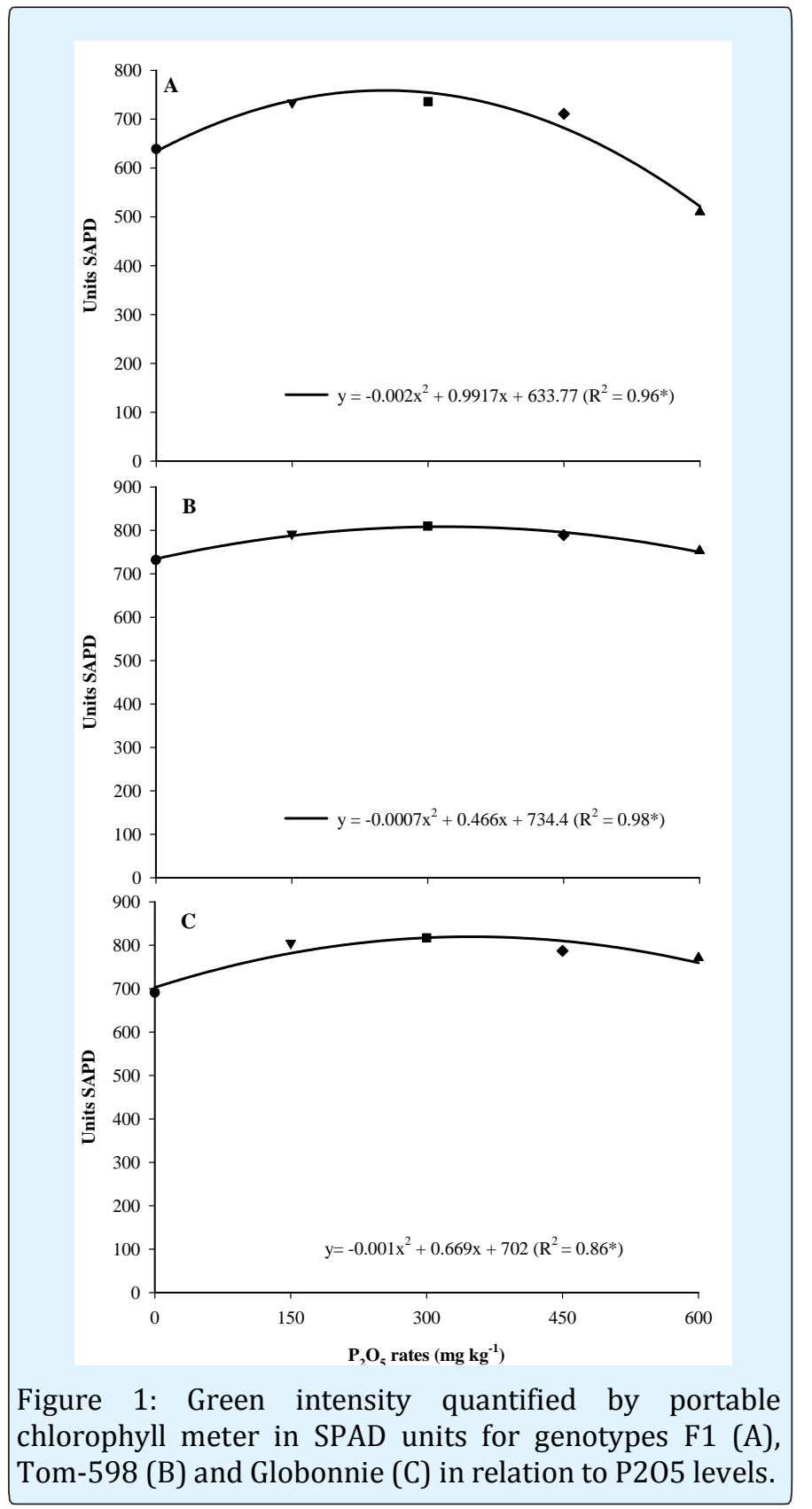

The genotypes conducted themselves in a distinct manner in relation to photosynthetic rate (Figure 2). The F1 (Figure 2A) and the Tom-598 (Figure 2B) showed an upward trend up to the dose of $450 \mathrm{mg}$ P2O5 kg-1 and Globonnie (Figure 2C) increased the photosynthetic activity according to the doses of P2O5.

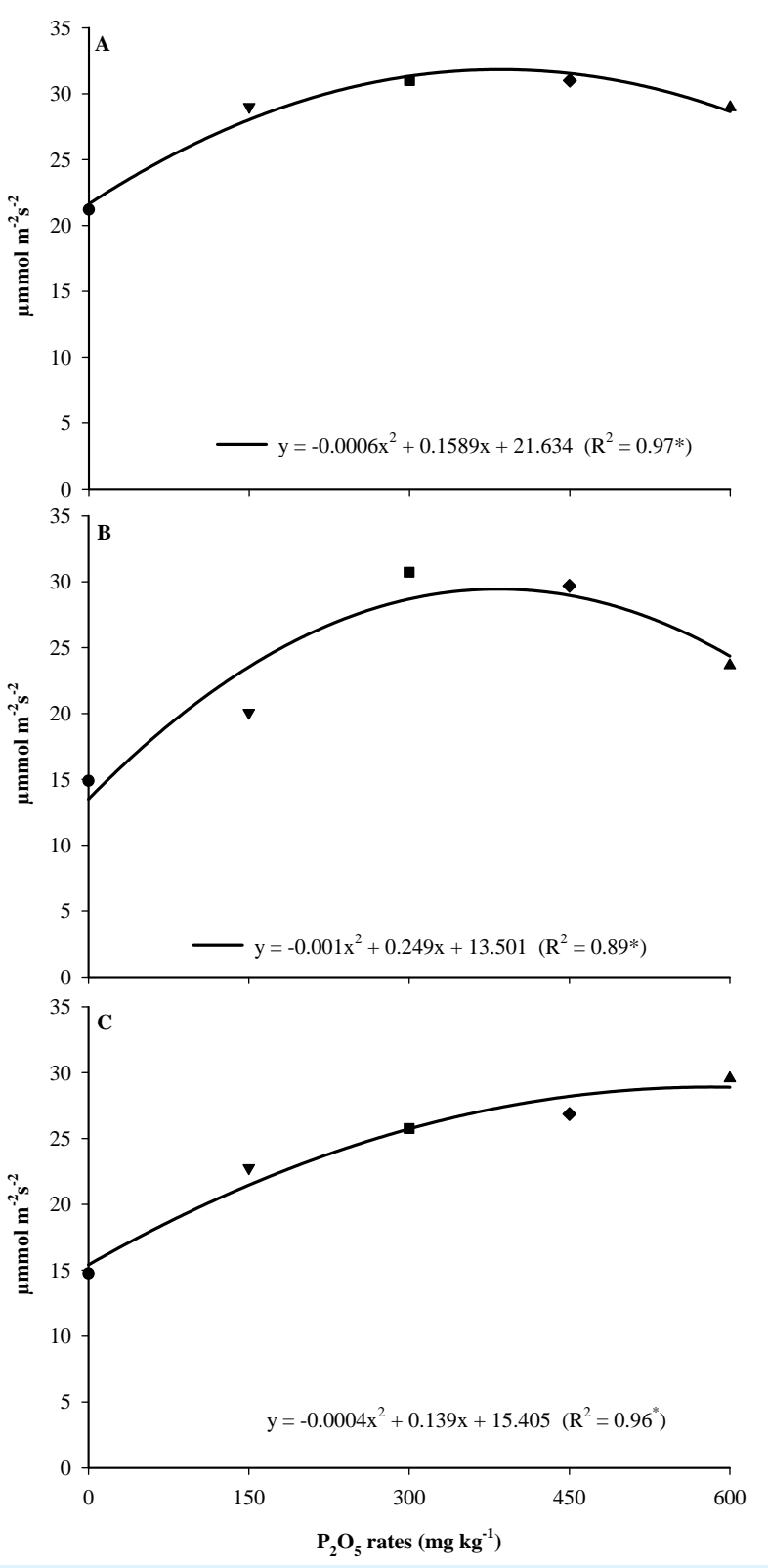

Figure 2: Photosynthetic rate $(\mu \mathrm{mmol} \mathrm{m}-2 \mathrm{~s}-2)$ genotypes F1 (A), TOM-598 (B) and Globonnie (C) in relation to P205 levels.

The observed differences in photosynthetic rate between genotypes can be explained by the intensity of 


\section{Open Access Journal of Agricultural Research}

the green color and its relation to the increase in plant chlorophyll content (Figure 1). According to Baker \& Rosenqvist (2004) [19], the absorption and use of light energy by plants can be estimated by chlorophyll fluorescence analysis due to the main function of chlorophyll is to absorb photons of light emitted by the sun, participating in the electron transport chain and ATP production.

The variation in photosynthetic rate can also be related to the number of leaves of genotypes (Figure 3). The genotype Tom-598 tended to increase in number of leaves depending on P205 doses, providing greater photosynthetic rate. The number of leaves is an important variable to be directly related to the possibility of greater light absorption, higher photosynthetic capacity and the production of photoassimilates [20]. Moreover, the low concentration of $\mathrm{P}$ in the plant limits the photosynthetic activity by means of regulatory mechanisms, and restricting the formation and carboxylation of rubisco and the light use efficiency [21]. The genotype Globonnie, when compared to the others, showed a lower content of $\mathrm{P}\left(\mathrm{g} \mathrm{kg-}{ }^{1}\right)$, independent of the P205 dose used. In genotype Tom-598 there was an upward trend in the $\mathrm{P}$ content $\left(\mathrm{g} \mathrm{kg}^{-1}\right)$ with the Increase of P205 doses (Figure $3 \mathrm{~A}$ ). As for $\mathrm{F} 1$, although the hybrid presents $50 \%$ of the alleles in relation to genotypes Globonnie and Tom-598, there was intermediate performance. For the genotypes analyzed, $P$ absorption efficiency had distinct performance in relation to P205 doses (Figure 3B). In Globonnie and Tom-598, the efficiency was crescent up to $300 \mathrm{mg} \mathrm{kg}-{ }^{1} \mathrm{P} 205$, in genotype $\mathrm{F} 1$ there was a decrease in $\mathrm{P}$ absorption efficiency with rising doses of P205.

These results are in agreement with Lacerda, et al. (2010) [22], who observed an increase in absorption efficiency at lower doses of P205. According to Vance, et al. (2003) [23] plant species and genotypes within the same species, may differ in nutritional efficiency. For $\mathrm{P}$ utilization efficiency (Figure 3C), the genotypes had different performances. The Globonnie and F1 presented mild increasing trend until the dose of $450 \mathrm{mg} \mathrm{kg-}{ }^{1}$ P2O5. This trend can be explained by the presence of $50 \%$ of Globonnie allele into the F1 genotype, showing the expression of the crtgene (Cotton root) in the P utilization efficiency because, regardless of the amount of $\mathrm{P}$ applied, the efficiency of genotype utilization, to biomass conversion is minimal. According to Viégas IDEJM, et al. (2017) [24] tolerance to abiotic stress, in some cases, is polygenic, relatively low heritability, which brings difficulties to the character transference. Furlani, et al. (1998) [25] reported that the characteristics related to $P$ absorption efficiency are also polygenic, additive and dominant character. On the other hand, genotype Tom598 showed a linear trend to the increase in doses, as noted by Lacerda, et al. (2010) [22].

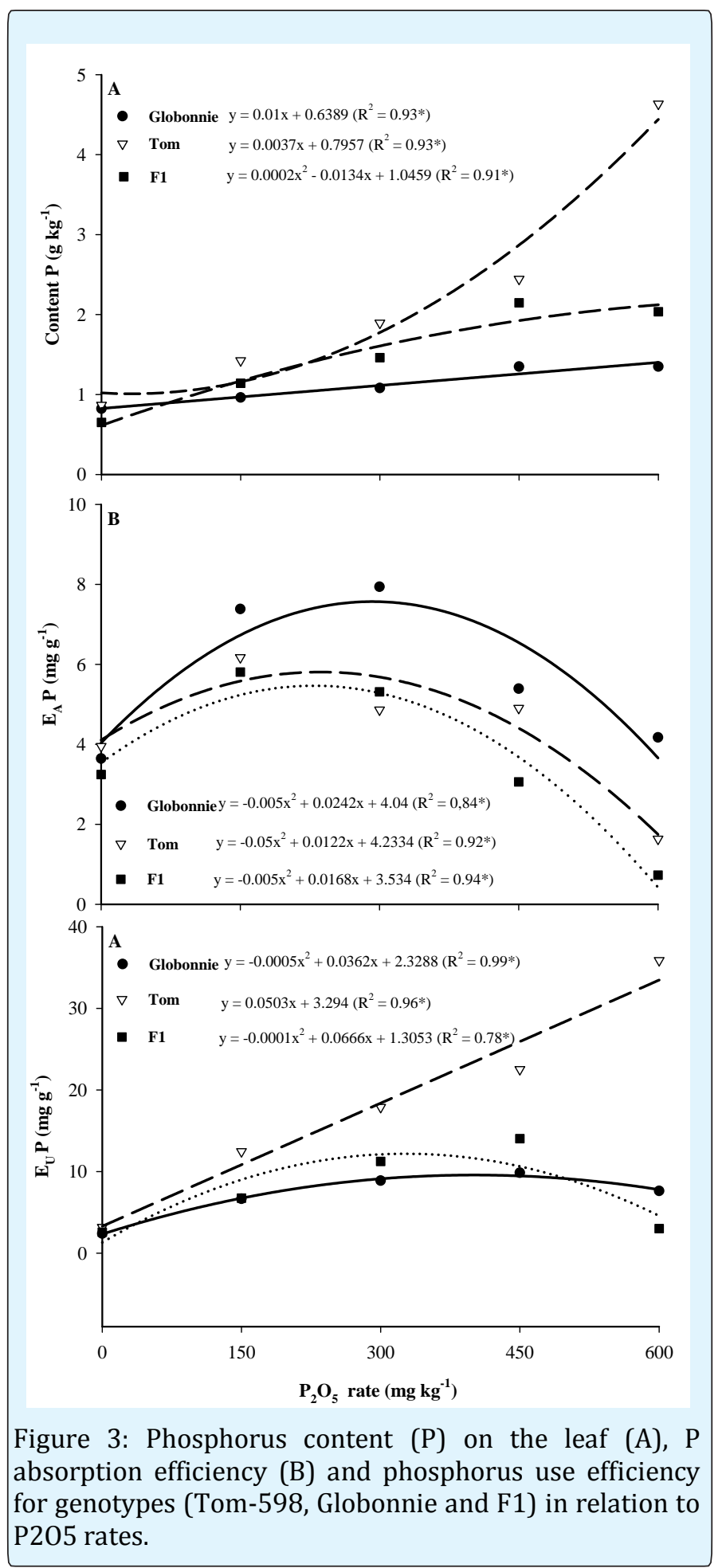




\section{Open Access Journal of Agricultural Research}

\section{Conclusion}

In the tomato crop, the increase in P205 doses provided:

a) Lower dry matter in stem, leaves and root in F1.

b) Higher intensity of the green color, measured by portable chlorophyll meter (SPAD), in Tom-598 and Globonnie.

c) Increased photosynthetic rate in Globonnie.

d) Increased phosphorus accumulation in Tom-598.

e) Greater phosphorus absorption efficiency in Globonnie, demonstrating expression of the crt gene (Cotton root)

f) Increased $P$ utilization efficiency in Tom-598, regardless of the dose used.

\section{References}

1. (2018) Faostat - Food and Agriculture Organization of the United Nations 2018.

2. Silva EC, Maluf WR (2012) Técnica hidropônica para triagem de genótipos de tomateiro quanto à eficiência de absorção de fósforo. Horticultura Brasileira 30(2): 324-328.

3. RAIJ BV (2011) Fertilidade do solo e manejo de nutrientes. Piracicaba, IPNI pp: 420.

4. Cordell D, Drangert JO, White S (2009) The story of phosphorus: Global food security and food for thought. Global Environmental Change 19(2): 292305.

5. Lynch J (1998) The role of nutrient efficient crops in modern agriculture. Journal of Crop Production 1(2): 241-64.

6. Marschner P, Solaiman Z, Rengel Z (2006) Rhizosphere properties of Poaceae genotypes under $P$ limiting conditions. Plant Soil 283(1-2): 11-24.

7. Richardson AE, Barea JM, Mcneill AM, PrigentCombaret C (2009) Acquisition of phosphorus and nitrogen in the rhizosphere and plant growth promotion by microorganisms. Plant Soil 321(1-2): 305-339.

8. Hochmuth GJ, Gabelman WH, Gerloff GCA (1985) gene affecting tomato root morphology. HortScience 20(6): 1099-1101.

9. Novais RF (1991) Métodos de pesquisa em fertilidade do solo: ensaio em ambiente controlado. Brasília: EMBRAPA-SEA pp: 392.
10. (2006) Empresa Brasileira De Pesquisa Agropecuária. Centro Nacional de Pesquisa de Solos. Sistema brasileiro de classificação de solos. $2^{\text {nd }}$ (edn.), Brasília: Embrapa-SPI; Rio de Janeiro: Embrapa Solos, pp: 306.

11. Malavolta E, Vitti GC, Oliveira SA (1997) Avaliação do estado nutricional das plantas: princípios e aplicações 2nd (edn.), rev atual Piracicaba: POTAFÓS pp: 319.

12. Ferreira D (2011) Sisvar: a computerstatisticalanalysis system.

CiênciaeAgrotecnologia, 35(6): 1039-1042.

13. Guimarães MA, Silva DJH, Peternelli LA, Fontes PCR (2009) Distribuição de fotoassimilados em tomateiro com e sem a retirada do primeiro cacho. Bioscience Journal, Uberlândia 25(5): 83-92.

14. Marques DJ, Silva EC, Moraes LFR, Caetano E, Silva RA, (2007) Introgressão e caracterização de gene de resistência a deficiência de fósforo em tomateiro. In: Congresso Brasileiro De Melhoramento De Plantas, IV. Resumos. São Lourenço: ABMP (CD-ROM).

15. Dovale JC, Fritsche-Neto R (2013) Genetic control of traits associated with phosphorus use efficiency in maize by REML/BLUP. Revista Ciência Agrônomica 44(3): 554-563.

16. Svistoonoff S, Cref A, Reymond M, Sigoillot-Claude C, Ricaud L, et al. (2007) Root tip contact with lowphosphate media reprograms plant root architecture. Nat Genet 39(6): 192-196.

17. Santos MG dos, Ribeiro RV, Oliveira RF de, Machado EC, Pimentel C (2006) The role of inorganic phosphate on photosynthesis recovery of common bean after a mild water deficit. Plant Science 170(3): 659-664.

18. Marenco RA, lopes NF (2009) Fisiologia vegetal: fotossíntese, respiração, relações hídricas e nutrição mineral. Editora: UFV: 47-70.

19. Baker NR, Rosenqvist E (2004) Applications of chlorophyll fluorescence can improve crop production strategies: an examination of future possibilities. J Exp Bot 55(403): 1607-1621.

20. Gonzalez-Sanpedro MC, Toan TLE, Moreno J, Kergoat L, Rubio E (2008) Seasonal variations of leaf area index of agricultural fields retrieved from Landsat 


\section{Open Access Journal of Agricultural Research}

data. Remote Sensing of Environment 112(3): 810824.

21. Campbell CD, Sage RF (2006) Interactions between the effects of atmospheric $\mathrm{CO} 2$ content and $\mathrm{P}$ nutrition on photosynthesis in white lupin (Lupinus albus L). Plant Cell and Environment 29(5): 844-853.

22. Lacerda JJJ, Santos JZL, Neto Furtini AE, Resende AV, Carneiro LF, et al. (2010) Eficiência de Absorção e Utilização de $\mathrm{P}$ pelo Feijoeiro em Solos de Cerrado com Diferentes Históricos de Uso.

23. Vance CP, Uhde-Stone C, Allan D (2003) Phosphorus acquisition and use: critical adaptations by plants securiting a nonrenewable resource. New Phytologist 157(3): 423-457.

24. Viégas I.DEJM, Naiff APM, Conceição HEO, Lobato AKDAS, Frazão DAC, Cordeiro RAM (2017) Visual symptoms, growth and nutrients of Alpinia purpurata plants exposed to $\mathrm{N}, \mathrm{P}, \mathrm{K}, \mathrm{Ca}, \mathrm{Mg}$ and $\mathrm{S}$ deficiencies. Journal of Food, Agriculture \& Environment 9(3-4): 1048-1051.

25. Furlani AMC, Lima M, Nass LL (1998) Combining ability effects for P-efficiency characters in maize grown in low $\mathrm{P}$ nutrient solution. Maydica, Bergamo 43(2): 169-174. 